\title{
HUBUNGAN MINAT MEMBACA, PENGUASAAN KOSAKATA, DAN NILAI RAPOR TERHADAP KETERAMPILAN BERPIDATO SISWA KELAS IX
}

\author{
Yoga Pradana Wicaksono dan Haryadi \\ Pendidikan Bahasa dan Sastra Indonesia, Universitas Negeri Yogyakarta \\ hyugha.dana@gmail.com
}

\begin{abstract}
ABSTRAK
Penelitian ini memiliki empat tujuan. Tujuan pertama untuk mengetahui hubungan minat membaca terhadap keterampilan berpidato siswa, kedua hubungan penguasaan kosakata terhadap keterampilan berpidato siswa, ketiga hubungan nilai rapor terhadap keterampilan berpidato siswa, dan keempat hubungan minat membaca, penguasaan kosakata, dan nilai rapor terhadap keterampilan berpidato siswa. Penelitian ini merupakan penelitian ex post facto jenis korelasional. Populasi penelitian ini adalah siswa kelas IX SMP N di Kabupaten Magelang. Pengambilan data menggunakan cluster sampling (area sampling), stratified random sampling, dan cluster random sampling. Pengumpulan data menggunakan angket, tes pilihan ganda, dokumentasi, dan tes pidato. Analisis data menggunakan teknik regresi sederhana dan regresi berganda. Hasil menunjukkan (1) minat membaca berhubungan dengan positif dan signifikan keterampilan berpidato, (2) penguasaan kosakata berhubungan dengan positif dan signifikan keterampilan berpidato, (3) nilai rapor berhubungan dengan positif dan signifikan keterampilan berpidato (4) minat membaca, penguasaan kosakata, dan nilai rapor secara bersama-sama berhubungan signifikan dengan keterampilan berpidato.
\end{abstract}

Kata Kunci: minat membaca, penguasaan kosakata, nilai rapor, keterampilan berpidato

\section{THE RELATIONSHIP BETWEEN THE READING INTEREST, VOCABULARY MASTERY, AND REPORT OF RESULT STUDY AND THE SPEECH DELIVERING SKILLS OF GRADE IX STUDENTS}

\begin{abstract}
The research has four purposes. The first objective to know the relationship between students' reading interest and their speech delivering skills, second the relationship between students' vocabulary mastery and their speech delivering skills, third the relationship between students' report of result study and their speech delivering skills, and fourth the relationship between students' reading interest, vocabulary mastery, and report of result study as an aggregate and their speech delivering skills. This was an ex post facto study correlational. The research population comprised Grade IX students of public junior high schools (JHSs) in Magelang Regency. The research sample was from three schools selected by means of the cluster sampling (area sampling), stratified random sampling, and cluster random sampling. Data collection using a questionnaire, multiple choice test, documentation, and speech delivering test. The data were analyzed by simple regression and multiple regression. The results of the study show that: (1) the reading interest has a significant positive relationship with the speech delivering skills, (2) the vocabulary mastery has a significant positive relationship with the speech delivering skills, (3) the report of result study have a significant positive relationship with the speech delivering skills, and (4) the reading interest, vocabulary mastery, and report of result study as an aggregate have a significant relationship with the speech delivering skills.
\end{abstract}

Keywords: reading interest, vocabulary mastery, report of result study, speech delivering skills 


\section{PENDAHULUAN}

Pidato merupakan salah satu keterampilan berbicara di depan publik yang memiliki peran sangat penting. Banyak tokoh dunia menggunakan kemampuan lisan ini untuk mengarahkan masyarakat ke arah yang orator inginkan. Pengaruh tersebut dapat berupa pengaruh untuk menciptakan perdamaian ataupun digunakan untuk mengobarkan semangat peperangan. Keraf (2004: 358) mengemukakan bahwa pidato dapat mengantarkan manusia menuju pada tingkatan kebudayaan yang lebih luhur, tetapi dapat juga menenggelamkan kebudayaan yang telah lama dibangun.

Keterampilan berpidato membutuhkan latihan supaya dapat dikuasai. Komunikasi dalam pidato berbeda dengan komunikasi pada umumnya karena dalam kegiatan ini orator mendominasi segala bentuk pembicaraan. Hendrikus (1991: 48) menyampaikan bahwa pidato merupakan salah satu bentuk monologika yaitu, seni berbicara secara monolog. Kegiatan monologika hanya terdapat satu orang yang dengan lantang menyampaikan gagasan-gagasan kepada para pendengar. Seseorang perlu untuk selalu berlatih baik mental maupun olah wicara supaya dapat membawakan pidato dengan baik.

Pidato merupakan salah satu keterampilan yang diajarkan di dalam KTSP mata pelajaran bahasa Indonesia kelas IX SMP. Oleh karena itu, keterampilan berpidato perlu dipahami dengan baik oleh siswa. Pidato membutuhkan praktik dalam pembelajaran. Namun, banyak guru hanya menyampaikan pidato tanpa memberikan praktik kepada siswa. Hal tersebut disebabkan karena waktu pembelajaran dan kemampuan guru yang terbatas untuk mendalami keterampilan berpidato. Selain itu, banyak sekolah yang tidak mencantumkan kegiatan berpidato dalam program ekstrakulikuler.

Pengetahuan dan skemata dapat diperluas dengan cara meningkatkan minat membaca. Minat membaca merupakan kebiasaan yang sangat baik dan perlu untuk selalu ditingkatkan oleh siapa saja. Kebiasaan membaca dapat memberikan berbagai manfaat yang sangat berguna untuk membangun peradaban. Selain itu, minat membaca juga dapat menambah wawasan dan pengalaman bagi orang yang melakukan aktivitas tersebut.
Setiap orang memiliki kemampuan membaca yang berbeda-beda. Perbedaan kemampuan tersebut dapat berupa kecepatan dalam membaca, kemampuan menangkap informasi, ataupun durasi yang digunakan. Dalman (2013: 45-46) menyampaikan bahwa seseorang dapat dikatakan sebagai pembaca yang baik apabila mampu mengatur kecepatan membaca, sesuai dengan tujuan, kebutuhan, dan mampu menjawab 60\% dari bahan yang telah dibaca.

Membaca dapat memberikan berbagai manfaat bagi pembaca. Namun, banyak siswa yang enggan melakukan aktivitas tersebut dalam kesehariannya. Salah satu penyebab minat membaca siswa yang rendah ialah tidak adanya contoh dalam hidup siswa. Guru sebagai pendidik banyak yang tidak memiliki minat membaca yang baik termasuk orang tua siswa.

Perpustakaan sekolah merupakan tempat yang seharusnya dapat meningkatkan minat membaca siswa. Namun, kondisi perpustakaan yang terdapat di sekolah kondisinya banyak yang memprihatinkan. Perpustakaan identik dengan gudang buku dan kondisinya banyak yang tidak terawat. Koleksi yang terdapat di dalam perpustakaan sebagian besar hanya berisi kumpulan buku pelajaran tanpa adanya buku yang mampu menarik minat membaca siswa. Kondisi perpustakaan yang demikian, menyebabkan banyak siswa yang enggan untuk mengunjunginya. Padahal, apabila sekolah ingin maju dan berhasil seharusnya perpustakaan tidak sepi dari pengunjung.

Minat membaca dapat meningkatkan pengetahuan, wawasan, dan skemata. Meningkatkanya pengetahuan, wawasan, dan skemata tersebut dapat membantu meningkatkan keterampilan dalam berpidato. Seorang orator harus dapat menyampaikan informasi yang beragam dan menarik, sehingga pendengar antusias mengikuti jalannya pidato. Informasi yang beragam dalam pidato tersebut dapat diperoleh dengan cara meningkatkan minat membaca.

Minat membaca dapat meningkatkan keragaman kosakata. Kosakata merupakan komponen penting yang digunakan untuk berkomunikasi secara langsung dengan orang lain. Barcroft, Sunderman, dan Schmitt (dalam Simpson, 2011: 576) menyampaikan bahwa kosakata sangat diperlukan dalam interaksi karena 
kosakata dapat menjamin suksesnya komunikasi yang sedang dijalin. Pengetahuan kosakata yang cukup dapat membantu melancarkan seseorang untuk dapat menyampaikan maksud dan tujuan kepada orang lain dengan lebih sempurna.

Kosakata merupakan komponen penting dalam berbahasa. Seseorang yang memiliki penguasaan kosakata yang baik akan lebih mudah dalam berkomunikasi. Segala bentuk pemikiran dapat disampaikan dengan lancar karena kosakata dapat mewakili apa yang dipikirkan. Penguasaan kosakata dapat mempengaruhi kemampuan seseorang ketika berpidato karena berpidato juga membutuhkan kemampuan komunikasi yang lancar dan jelas. Penyampaian pidato yang jelas dan lancar membantu pendengar menangkap informasi yang disampaikan.

Manusia merupakan mahkluk yang paling sempurna. Manusia memiliki kelebihan yang tidak dimiliki oleh mahluk lain. Kelebihan yang dimaksud dapat berupa kemampuan dalam berpikir. Kemampuan berpikir membuat manusia selalu mencari, mempelajari, dan memahami berbagai fenomena-fenomena yang ada disekelilingnya. Kemampuan dalam berpikir merupakan salah satu kemampuan kognitif yang dimiliki manusia.

Aktivitas kognitif merupakan aktivitas yang berkaitan dengan proses mental dan proses berpikir seseorang. Smith dan Stephen (2014: 3) mengutarakan bahwa kognitif dapat disebut sebagai aktivitas mental, merupakan interpretasi atau transformasi internal atas informasi yang tersimpan. Setiap orang memperoleh informasi dari berbagai sumber yang ditangkap menggunakan panca indra, kemudian disimpan di dalam ingatan (memory) masing-masing.

Stenberg (2008,p.2) mengemukakan bahwa kognitif merupakan cara manusia dalam berpikir untuk menanggapi suatu informasi. Oleh sebab itu, kemampuan kognitif memandu manusia dalam memahami berbagai fenomena yang ada disekitarnya. Kemampuan kognitif dapat berupa kecerdasan, kemampuan dalam berbahasa, nalar, dan emosi. Kecerdasan membentuk manusia menjadi mahluk yang memiliki rasa ingin tahu yang tinggi terhadap hal-hal baru. Selain itu, kognitif juga memberikan efek terhadap proses akuisis dan pemahaman akan bahasa.

Reed (2011: 2) mengutarakan bahwa kognitif merupakan proses pemerolehan pengetahuan. Pengetahuan yang diperoleh seseorang dapat meningkatkan kecerdasan, meningkatkan kemampuan dalam berbahasa, mendewasakan emosi, dan penalaran. Kaitannya dengan siswa, kemampuan kognitif tersebut sebagian tercermin dari nilai rapor yang siswa miliki. Nilai rapor menggambarkan tingkat keberhasilan siswa dalam menyelesaikan pendidikan dan seberapa tinggi kemampuan kognitif yang siswa miliki. Kemampuan kognitif sangat diperlukan dalam aktivitas berpidato. Berpidato merupakan bentuk komunikasi yang sama sekali berbeda dengan komunikasi pada umumnya. Pidato membutuhkan kecerdasan dalam memilih dan menyusun informasi, kemampuan dalam menyampaikan kepada pendengar menggunakan bahasa, dan kemampuan mengambil hati pendengar dengan kemampuan emosi yang dimiliki. Berbekal kemampuan tersebut, maka dapat dipastikan pidato yang dilaksanakan dapat berjalan sesuai dengan rencana.

Adapun tujuan penelitian adalah untuk (1) mengetahui hubungan antara minat membaca dengan keterampilan berpidato pada siswa kelas IX SMP Negeri di Kabupaten Magelang, (2) mengetahui ada tidaknya hubungan antara penguasaan kosakata dengan keterampilan berpidato pada siswa kelas IX SMP Negeri di Kabupaten Magelang, (3) mengetahui ada tidaknya hubungan antara nilai rapor dengan keterampilan berpidato pada siswa kelas IX SMP Negeri di Kabupaten Magelang, dan (4) mengetahui ada tidaknya hubungan antara minat membaca, penguasaan kosakata, dan nilai rapor secara bersama-sama terhadap keterampilan berpidato pada siswa kelas IX SMP Negeri di Kabupaten Magelang.

\section{METODE PENELITIAN}

Penelitian ini merupakan penelitian dengan menggunakan metode ex post facto. Desain penelitian ini adalah desain korelasional. Penelitian ini dilaksanakan pada semester genap tahun ajaran 2015/2016 pada bulan Maret sampai dengan April 2016. Tempat penelitian adalah SMP Negeri di Kabupaten Magelang. 
Populasi dalam penelitian ini adalah seluruh siswa kelas IX yang berasal dari 59 SMP Negeri di Kabupaten Magelang tahun ajaran 2015/2016. Penyampelan dalam penelitian ini dilakukan dengan menggunakan tiga teknik, teknik pertama untuk menentukan sampel daerah, teknik kedua untuk menentukan sekolah, dan teknik ketiga untuk menentukan kelas. Pengambilan sampel pertama menggunakan teknik area sampling(sampel wilayah). Pengambilan sampel kedua menggunakan stratified random sampling atau pengambilan data berdasarkan strata terhadap sekolah. Teknik ketiga menggunakan teknik cluster random sampling untuk menentukan kelas yang akan digunakan sebagai subjek penelitian. Variabel bebas dalam penelitian ini adalah minat membaca, penguasaan kosakata, dan nilai rapor. Variabel terikat dalam penelitian ini adalah keterampilan berpidato.

Teknik pengumpulan data dalam penelitian ini berbentuk tes dan nontes. Berdasarkan teknik pengumpulan data tersebut, terdapat empat jenis data yang akan dikumpulkan yaitu, data keterampilan berpidato, data minat membaca, data penguasaan kosakata, dan data nilai rapor.

Pengumpulan data keterampilan berpidato diukur menggunakan tes unjuk kerja (praktik berpidato). Pengukuran dan pengambilan data minat membaca menggunakan teknik nontes berbentuk angket minat membaca. Pengumpulan data penguasaan kosakata menggunakan tes objektif bentuk pilihan ganda, sedangkan pengumpulan data nilai rapor menggunakan teknik nontes yang diambil dari nilai rapor siswa.

Teknik analisis data dalam penelitian ini menggunakan teknik regresi baik secara sederhana maupun berganda. Kriteria penerimaan dan penolakan hipotesis dalam penelitian ini menggunakan taraf signifikasi 0,05 . Seluruh penghitungan menggunakan program SPSS 20.

\section{HASIL DAN PEMBAHASAN}

Hasil uji normalitas menunjukkan data berdistribusi normal. Berdasarkan hasil uji linearitas menunjukkan data variabel bebas dan variabel terikat berdistribusi linear. Uji multikoleniaritas menunjukkan bahwa di antara variabel bebas tidak terjadi multikoleniaritas. Uji prasyarat terakhir yaitu uji heteroskedastisitas, berdasarkan uji tersebut menunjukkan bahwa data tidak terjadi heteroskedastisitas. Semua uji prasyarat telah terpenuhi, sehingga uji statistik untuk menguji hipotesis dapat dilakukan. Terdapat empat hipotesis dalam penelitian ini yaitu (1) ada hubungan yang positif dan signifikan antara minat membaca terhadap keterampilan berpidato siswa kelas IX SMP Negeri di Kabupaten Magelang, (2) ada hubungan yang positif dan signifikan antara penguasaan kosakata terhadap keterampilan berpidato siswa kelas IX SMP Negeri di Kabupaten Magelang, (3) ada hubungan yang positif dan signifikan antara nilai rapor terhadap keterampilan berpidato siswa kelas IX SMP Negeri di Kabupaten Magelang, dan (4) ada hubungan yang positif dan signifikan antara minat membaca, penguasaan kosakata, dan nilai rapor terhadap keterampilan berpidato siswa kelas IX SMP Negeri di Kabupaten Magelang.

Uji hipotesis sederhana dilakukan dengan menggunakan teknik uji t regresi. Penggunaan uji t regresi dalam hipotesis sederhana ini bertujuan untuk mengetahui hubungan minat membaca, penguasaan kosakata, dan nilai rapor terhadap keterampilan berpidato secara sederhana.

Tabel 1. Uji Regresi Sederhana (Uji t Regresi) Minat Membaca dengan Berpidato

\begin{tabular}{|l|c|c|c|c|c|}
\hline \multirow{2}{*}{ Model } & \multicolumn{2}{|c|}{$\begin{array}{c}\text { Koefisien tidak } \\
\text { Distandarisasi }\end{array}$} & $\begin{array}{c}\text { Koefisien } \\
\text { Distandarisasi }\end{array}$ & \multirow{2}{*}{$\mathrm{t}$} & \multirow{2}{*}{ Sig. } \\
\cline { 2 - 4 } & $\mathrm{B}$ & $\begin{array}{c}\text { Std. } \\
\text { Error }\end{array}$ & Beta & & \\
\hline & $-2,584$ & 3,483 & & $-0,74$ & 0,460 \\
\hline $\begin{array}{l}\text { (Constant) } \\
\text { Minat }\end{array}$ & $-2,175$ & 0,028 & 0,546 & & \\
\hline
\end{tabular}

Tabel 1 menunjukkan hasil regresi sebesar $\hat{Y}=-2,584+0,175$ X1. Hasil itu memberikan sebuah prediksi bahwa apabila variabel minat membaca (X1) meningkat 1 digit, maka keterampilan berpidato akan meningkat 0,175. Semakin tinggi koefisien minat membaca semakin tinggi pula koefisien keterampilan berpidato. Hal tersebut menandakan terdapat hubungan yang searah antar minat membaca dengan keterampilan berpidato.

Berdasarkan hasil analisis regresi diperoleh nilai signifikasi $0,000<0,05$, maka dapat 
disimpulkan bahwa minat membaca memiliki hubungan signifikan terhadap keterampilan berpidato. Oleh karena itu, hipotesis yang menyatakan ada hubungan yang positif dan signifikan antara minat membaca $\left(\mathrm{X}_{1}\right)$ dengan keterampilan berpidato (Y) siswa kelas IX SMP Negeri di Kabupaten Magelang terbukti. Minat membaca berhubungan dengan keterampilan berpidato disebabkan karena minat membaca dapat meningkatkan pengetahuan, wawasan, dan kecerdasan. Pengetahuan sangat berguna untuk menunjang performa ketika berpidato. Pengetahuan memberikan keleluasaan orator dalam menyampaikan segala informasi yang beragam dan menarik. Kecerdasan mabantu orator untuk memilih informasi yang akan disampaikan kepada pendengar, sehingga lebih mengena dan berkesan dalam benak pendengar.

Kontribusi minat membaca terhadap keterampilan berpidato dapat dilihat dari koefisien determinasi hasil regresi sederhana antara minat mebaca dengan keterampilan berpidato melalui tabel 2 berikut.

Tabel 2. Regresi Sederhana Minat Membaca terhadap Keterampilan Berpidato

\begin{tabular}{c|c|c|c}
\hline Model & $\begin{array}{c}\mathbf{R} \\
\text { (Korelasi } \\
\text { Ganda) }\end{array}$ & $\begin{array}{c}\text { R Square } \\
\text { (Koefisien } \\
\text { Determinasi }\end{array}$ & $\begin{array}{c}\text { Adjusted } R \\
\text { Square }\left(\text { Nilai R } \mathbf{R}^{2} \text { ) }\right.\end{array}$ \\
\hline 1 & 0,546 & 0,299 & 0,291 \\
\hline
\end{tabular}

Tabel 2 tersebut menunjukkan koefisien determinasi $\left(R^{2}\right)$ sebesar 0,299. Hal itu memberikan makna bahwa minat membaca memberikan kontribusi sebesar $29,9 \%$ terhadap keterampilan berpidato, sedangkan sisanya yaitu $70,1 \%$ dipengaruhi oleh faktor lain.

Tabel 3. Uji Regresi secara Sederhana (Uji t Regresi) Penguasaan Kosakata dengan Berpidato

\begin{tabular}{|c|c|c|c|c|c|}
\hline \multirow{2}{*}{ Model } & \multicolumn{2}{|c|}{$\begin{array}{l}\text { Koefisien tidak } \\
\text { Distrandarisasi }\end{array}$} & \multirow{2}{*}{$\begin{array}{c}\begin{array}{c}\text { Koefisien } \\
\text { Distandarisasi }\end{array} \\
\text { Beta }\end{array}$} & \multirow{2}{*}{$\mathrm{t}$} & \multirow{2}{*}{ Sig. } \\
\hline & B & $\begin{array}{c}\text { Std. } \\
\text { Error }\end{array}$ & & & \\
\hline (Constant) & 5,204 & 2,275 & & 2,29 & 0,024 \\
\hline $\begin{array}{l}\text { Penguasaan } \\
\text { Kosakata }\end{array}$ & 0,582 & 0,093 & 0,543 & 6,24 & 0,000 \\
\hline
\end{tabular}

Tabel 3 tersebut menunjukkan hasil regresi sebesar $\hat{Y}=5,204+0,582$ X2. Hasil itu memberikan sebuah prediksi bahwa apabila variabel penguasaan kosakata (X2) meningkat 1 digit, maka keterampilan berpidato (Y) akan meningkat 0,582 . Semakin tinggi koefisien penguasaan kosakata (X2) semakin tinggi pula koefisien keterampilan berpidato $(\mathrm{Y})$. Hal itu mempertegas bahwa terdapat hubungan yang searah antar penguasaan kosakata (X2) dengan keterampilan berpidato $(\mathrm{Y})$.

Berdasarkan hasil analisis regresi diperoleh nilai signifikasi $0,000<0,05$, maka dapat disimpulkan bahwa penguasaan kosakata (X2) memiliki hubungan signifikan terhadap keterampilan berpidato (Y). Oleh karena itu, hipotesis yang menyatakan ada hubungan yang positif dan signifikan antara penguasaan kosakata $\left(\mathrm{X}_{2}\right)$ dengan keterampilan berpidato $(\mathrm{Y})$ siswa kelas IX SMP Negeri di Kabupaten Magelang terbukti. Penguasaan kosakata meningkatkan kemampuan dalam mengungkapkan segala bentuk pemikiran. Seseorang yang memiliki penguasaan kosakata yang berlimpah dapat terbantu ketika akan berbicara. Oleh sebab itu, penguasaan kosakata memiliki hubungan dengan keterampilan berpidato karena penguasaan kosakata yang berlimpah membantu mempermudah orator untuk mengungkapkan segala ide dan pengetahuan kepada pendengar, sehingga pendengar antusias dan tertarik mengikuti pidato tersebut.

Kontribusi penguasaan kosakata (X2) terhadap keterampilan berpidato $(\mathrm{Y})$ dapat dilihat dari koefisien determinasi hasil regresi sederhana antara penguasaan kosakata (X2) dengan keterampilan berpidato (Y) melalui tabel 4.

Tabel 4. Regresi Sederhana Penguasaan Kosakata terhadap Keterampilan Berpidato

\begin{tabular}{|c|c|c|c|}
\hline Model & $\begin{array}{c}\text { R } \\
\text { (Korelasi } \\
\text { Ganda) }\end{array}$ & $\begin{array}{c}\text { R Square } \\
\text { (Koefisien } \\
\text { Determinasi) }\end{array}$ & $\begin{array}{c}\text { Adjusted } R \text { Square } \\
\text { (Nilai } \mathbf{R}^{2} \text { ) }\end{array}$ \\
\hline 1 & 0,543 & 0,295 & 0,287 \\
\hline
\end{tabular}

Berdasarkan Tabel 4 menunjukkan koefisien determinasi $\left(\mathrm{R}^{2}\right)$ sebesar 0,295. Hal itu memberikan makna bahwa penguasaan kosakata 
memberikan kontribusi sebesar 29,5\% terhadap keterampilan berpidato, sedangkan sisanya yaitu $70,5 \%$ dipengaruhi oleh faktor lain.

Tabel 5. Hasil Uji Regresi Secara Sederhana (Uji t Regresi) Nilai Rapor dengan Berpidato

\begin{tabular}{|c|c|c|c|c|c|}
\hline \multirow{2}{*}{ Model } & \multicolumn{2}{|c|}{$\begin{array}{c}\text { Koefisien tidak } \\
\text { Distandarisasi }\end{array}$} & $\begin{array}{c}\text { Koefisien } \\
\text { Distandar } \\
\text { isasi }\end{array}$ & \multirow{2}{*}{$\mathrm{t}$} & Sig. \\
\cline { 2 - 5 } & $\mathrm{B}$ & $\begin{array}{c}\text { Std. } \\
\text { Error }\end{array}$ & Beta & & \\
\hline (Constant) & $-39,13$ & 11,85 & & $-3,303$ & 0,001 \\
\hline Nilai Rapor & 0,714 & 0,145 & 0,455 & 4,928 & 0,000 \\
\hline
\end{tabular}

Tabel 5 menunjukkan hasil regresi sebesar $\hat{Y}=-39,125+0,714$ X3. Hasil tersebut memberikan sebuah prediksi bahwa apabila variabel nilai rapor (X3) ditingkatkan, maka variabel keterampilan berpidato $(\mathrm{Y})$ juga akan ikut meningkat. Apabila nilai rapor (X3) meningkat 1 digit, maka keterampilan berpidato (Y) akan meningkat 0,714 . Semakin tinggi koefisien nilai rapor (X3) semakin tinggi pula koefisien keterampilan berpidato (Y). Hal itu mempertegas bahwa terdapat hubungan yang searah antar nilai rapor (X3) dengan keterampilan berpidato (Y).

Berdasarkan hasil analisis regresi diperoleh nilai signifikasi $0,000<0,05$, maka dapat disimpulkan bahwa nilai rapor (X3) memiliki hubungan signifikan terhadap keterampilan berpidato (Y). Oleh karena itu, hipotesis yang menyatakan ada hubungan yang positif dan signifikan antara nilai rapor $\left(\mathrm{X}_{3}\right)$ dengan keterampilan berpidato $(\mathrm{Y})$ siswa kelas IX SMP Negeri di Kabupaten Magelang terbukti.

Nilai rapor merupakan gambaran kemampuan kognitif yang siswa miliki. Kemampuan kognitif merupakan kemampuan yang menjadi tumpuan keterampilan manusia. Kemampuan kognitif tinggi yang ditunjukkan dalam nilai rapor memiliki hubungan dengan keterampilan dalam berpidato karena kemampuan kognitif merupakan kemampuan seseorang dalam berpikir dan menanggapi segala masalah yang berada di sekelilingnya. Kemahiran dalam berpikir dan menghadapi segala permasalahan sangat dibutuhkan dalam berpidato. supaya dapat memikat banyak pendengar ketika berpidato, seorang orator harus mampu meramu kemampuannya dalam mengungkap hal-hal menarik. Selain itu seorang orator juga perlu tenang dalam menghadapi segala permasalahan sehingga mampu dengan tenang menghadapi pendengar yang berasal dari banyak kalangan.

Kontribusi nilai rapor (X3) terhadap keterampilan berpidato (Y) dapat dilihat dari koefisien determinasi hasil regresi sederhana antara nilai rapor (X3) dengan keterampilan berpidato (Y) melalui tabel 6 .

Tabel 6. Regresi Sederhana Nilai Rapor terhadap Keterampilan Berpidato

\begin{tabular}{c|c|c|c|}
\hline Model & $\begin{array}{c}\mathbf{R} \\
\text { (Korelasi } \\
\text { Ganda) }\end{array}$ & $\begin{array}{c}\text { R Square } \\
\text { (Koefisien } \\
\text { Determinasi) }\end{array}$ & $\begin{array}{c}\text { Adjusted } \boldsymbol{R} \\
\text { Square (Nilai } \\
\mathbf{R}^{2} \text { ) }\end{array}$ \\
\hline 1 & 0,455 & 0,207 & 0,199 \\
\hline
\end{tabular}

Tabel 6 menunjukkan koefisien determinasi $\left(\mathrm{R}^{2}\right)$ 0,207. Hal tersebut memberikan makna bahwa nilai rapor memberikan kontribusi sebesar $20,7 \%$ terhadap keterampilan berpidato, sedangkan sisanya yaitu 79,3\% dipengaruhi oleh faktor lain.

Uji hipotesis ganda dilakukan dengan menggunakan teknik uji F regresi. Penggunaan uji $F$ regresi dalam hipotesis ganda ini bertujuan untuk mengetahui hubungan minat membaca, penguasaan kosakata, dan nilai rapor terhadap keterampilan berpidato secara simultan. Rangkuman hasil analisis uji regresi ganda dapat dilihat pada Tabel 6 .

Tabel 7. Hasil Uji Regresi Secara Berganda (Uji F Regresi)

\begin{tabular}{|l|c|c|c|c|c|}
\hline Model & $\begin{array}{c}\text { Sum of } \\
\text { Squares }\end{array}$ & df & $\begin{array}{c}\text { Mean } \\
\text { Square }\end{array}$ & F & Sig. \\
\hline Regression & 842,557 & 3 & 280,852 & 30,45 & 0,000 \\
\hline Residual & 839,233 & 91 & 9,222 & & \\
\hline Total & 1681,789 & 94 & & & \\
\hline
\end{tabular}

Tabel 7 menunjukkan $\mathrm{F}_{\text {hitung }}$ sebesar 30,453 dan p $0,000<0,05$. Regresi ganda dikatakan signifikan apabila nilai $\mathrm{p}$ kurang dari 0,05. Hasil uji F menunjukkan bahwa X1, X2, dan X3 berpengaruh terhadap Y karena nilai $p$ 
lebih kecil dari 0,05. Berdasarkan hasil tersebut dapat disimpulkan bahwa variabel bebas secara bersama-sama memiliki hubungan secara signifikan terhadap variabel terikat, sehingga hipotesis keempat terbukti kebenarannya.

Uji keabsahan beta dilakukan dengan tujuan untuk mengetahui variabel bebas yang paling dominan mempengaruhi keterampilan berpidato. Penentuan variabel yang paling dominan tersebut didasarkan pada nilai koefisien beta yang paling besar. Menentukan variabel bebas yang paling dominan dapat dilihat pada tabel 8 .

Tabel 8. Uji Keabsahan Beta

\begin{tabular}{|c|c|c|c|c|c|}
\hline \multirow[t]{2}{*}{ Variabel } & \multicolumn{2}{|c|}{$\begin{array}{c}\text { Koefisien } \\
\text { tidak } \\
\text { Distandarisasi }\end{array}$} & \multirow{2}{*}{$\begin{array}{c}\text { Koefisien } \\
\text { Distanda } \\
\text { risasi }\end{array}$} & \multirow[t]{2}{*}{$\mathbf{t}$} & \multirow[t]{2}{*}{ Sig. } \\
\hline & B & $\begin{array}{c}\text { Std. } \\
\text { Error }\end{array}$ & & & \\
\hline (constant) & $-34,28$ & 10,031 & & $-3,418$ & 0,001 \\
\hline $\begin{array}{l}\text { Minat } \\
\text { Membaca } \\
(\mathrm{X} 1)\end{array}$ & 0,131 & 0,025 & 0,408 & 5,262 & 0,000 \\
\hline $\begin{array}{l}\text { Penguasaa } \\
\text { n Kosakata } \\
(\mathrm{X} 2)\end{array}$ & 0,346 & 0,091 & 0,323 & 3,780 & 0,000 \\
\hline $\begin{array}{l}\text { Nilai } \\
\text { Rapor } \\
\text { (X3) }\end{array}$ & 0,353 & 0,131 & 0,225 & 2,698 & 0,008 \\
\hline
\end{tabular}

Berdasarkan tabel 8 diperoleh nilai beta dari masing-masing variabel bebas. Minat membaca (X1) menunjukkan nilai Beta yang paling tinggi dengan skor 0,408 dibandingkan variabel bebas yang lainnya. Kesimpulannya ialah variabel minat membaca merupakan variabel yang paling dominan mempengaruhi keterampilan berpidato. Hal tersebut terjadi karena minat membaca merupakan aktivitas yang dapat meningkatkan pengetahuan, wawasan, dan kecerdasan. Meningkatnya kemampuan tersebut tentunya berpengaruh terhadap banyak hal, terutamanya dalam keterampilan berpidato. Keterampilan berpidato sangat membutuhkan wawasan yang luas, tanpa memiliki pengetahuan dan wawasan yang luas sulit kiranya orator dalam mengembangkan materi ketika berada di atas panggung.

Uji determinasi $\left(\mathrm{R}^{2}\right)$ dilakukan dengan tujuan untuk mengetahui sumbangan relatif dari variabel bebas terhadap variabel terikat secara bersama-sama. Variabel bebas dikatakan memiliki sumbangan yang besar terhadap variabel terikan apabila nilai determinasi $\left(\mathrm{R}^{2}\right)$ semakin mendekati 1. Namun, apabila nilai determinasi tersebut semakin kecil mendakati 0, maka variabel bebas tersebut memberikan sumbangan yang kecil terhadap variabel terikat. Hasil uji determinasi $\left(\mathrm{R}^{2}\right)$ dapat dilihat pada tabel 9.

Tabel 9. Uji Determinasi $\left(\mathrm{R}^{2}\right)$

\begin{tabular}{|c|c|c|c|}
\hline Model & R & R Square & $\begin{array}{c}\text { Adjusted } \boldsymbol{R} \\
\text { Square }\end{array}$ \\
\hline 1 & 0,708 & 0,501 & 0,485 \\
\hline
\end{tabular}

Berdasarkan Tabel 9 diperoleh nilai Adjusted R Square sebesar 0,485. Hasil tersebut menunjukkan bahwa variabel minat membaca (X1), penguasaan kosakata (X2), dan nilai rapor (X3) mampu menjelaskan $48,5 \%$ variasi terhadap keterampilan berpidato (Y) atau 48,5\% perubahan terjadi pada variabel keterampilan berpidato (Y). Sementara sisanya sebesar 51,5\% $(100 \%-48,5 \%)$ dijelaskan oleh faktor lain selain dari variabel bebas.

\section{Hubungan Minat Membaca terhadap Kete- rampilan Berpidato Siswa Kelas IX SMP Negeri di Kabupaten Magelang}

Membaca merupakan kegiatan yang baik untuk dibiasakan karena akan menambah wawasan dan ilmu pengetahuan. Namun, setiap orang memiliki minat membaca yang berbedabeda. Berdasarkan analisis terhadap skor minat membaca siswa kelas IX SMP Negeri di Kabupaten Magelang memberikan gambaran seberapa besar minat membaca yang siswa miliki. Penggunaan sampel penelitian berjumlah 95 siswa, 21 siswa atau $22,10 \%$ memiliki minat membaca tinggi, 47 siswa atau $49,50 \%$ memiliki minat membaca sedang, dan 27 siswa atau $28,40 \%$ memiliki minat membaca rendah. Berdasarkan hasil tersebut dapat diketahui ratarata minat membaca siswa kelas IX SMP Negeri di Kabupaten Magelang dalam kategori baik.

Minat membaca yang baik tentu akan memberikan pengaruh dan manfaat terhadap kegiatan lain. Berdasarkan uji t yang telah dilakukan diketahui bahwa minat membaca memiliki hubungan terhadap keterampilan berpidato. 
Hubungan tersebut terlihat dari koefisien beta sebesar 0,174 dan bernilai positif. Nilai positif memiliki makna bahwa apabila minat membaca seseorang meningkat, maka keterampilan berpidatonya juga akan ikut meningkat. Selain itu, hasil uji hubungan tersebut menunjukkan koefisien determinasi minat membaca terhadap keterampilan berpidato sebesar $29,9 \%$, sedangkan $70,1 \%$ sisanya dijelaskan oleh faktor lain.

Membaca merupakan kegiatan positif yang memberikan manfaat bagi pembaca. Dawson (via Tarigan, 2008: 4) megutarakan bahwa membaca dapat meningkatkan kemampuan lisan seseorang, seperti kesadaran terhadap istilah-istilah baru, meningkatkan efektifitas dan penggunaan kalimat yang lebih baik, dan meningkatkan kemampuan dalam menggunakan kata-kata dengan tepat. Kemampuan lisan merupakan tumpuan utama dalam berpidato. Supaya pidato dapat berjalan seperti yang telah direncaanakan, seorang orator dituntut dapat menggunakan bahasa lisan dengan baik agar dapat memikat dan mempengaruhi pendengar. Selain itu, kegiatan membaca dapat meningkatkan pengetahuan dan wawasan. Pengetahuan yang luas dari orator dapat menyegarkan pengetahuan pendengar dan membantu orator supaya tidak monoton ketika berpidato. Pendengar akan mudah tertarik dan terkesima apabila orator menyampaikan hal-hal baru yang belum pernah pendengar ketahui sebelumnya. Penggunaan informasi yang kurang inovatif dapat menyebabkan pendengar lebih cepat merasa bosan dan tidak mengundang rasa penasaran, sehingga pemaparan yang disampaikan orator menjadi mudah ditebak.

Menyadari manfaat dari kegiatan membaca, setiap individu seharusya mulai tergugah dan mulai menumbuhkan minat membaca dalam diri masing-masing. Membaca seperti yang diungkapkan Dawson dan dari hasil penelitian ini telah membuktikan bahwa membaca memiliki hubungan terhadap keterampilan berpidato. Membaca tidak semata-mata meningkatkan pengetahuan seseorang, tetapi membaca juga meningkatkan kualitas olah vokal bagi para pembaca.

Minat membaca yang baik ialah minat membaca yang tidak hanya terfokus pada satu genre bacaan. Minat membaca harus selalu ditumbuhkan dalam segala lingkup bacaan yang lebih luas, sehingga dapat memperluas cakrawala pembaca. Tarigan (2008: 105) mengutarakan bahwa orang yang buta huruf dan sempit pengetahuan ditandai oleh minat membaca yang amat sempit dan terbatas pada satu genre. Minat membaca yang luas meningkatkan kemampuan orator dalam mengambil hati pendengar ketika berpidato karena dalam berpidato pendengar berasal dari kalangan yang luas, sehingga perlu didekati dengan pengetahuan yang luas pula.

Hasil penelitian ini sejalan dengan penelitian yang telah dilakukan oleh Yuliatun (2009) yang menyatakan bahwa minat membaca berhubungan dengan keterampilan berpidato pada siswa SD. Penelitian ini mengungkapkan fakta yang serupa bahwa minat membaca berhubungan dengan keterampilan berpidato pada lingkup siswa yang lebih tinggi yaitu pada siswa SMP.

\section{Hubungan Penguasaan Kosakata terhadap Keterampilan Berpidato Siswa Kelas IX SMP Negeri di Kabupaten Magelang}

Penguasaan kosakata merupakan kemampuan seseorang dalam menggunakan kata-kata dalam bahasa yang dikuasai. Setiap orang pasti memiliki penguasaan kosakata terutama dalam bahasanya sendiri. Namun, penguasaan kosakata setiap orang tidaklah sama, ada yang tinggi, sedang, dan ada pula yang rendah. Berdasarkan hasil penelitian yang telah dilakukan terhadap siswa kelas IX SMP Negeri di Kabupaten Magelang terlihat gambaran penguasaan kosakata dari masing-masing siswa. Sampel penelitian yang berjumlah 95 siswa, 44 siswa atau 46,30\% memiliki penguasaan kosakata yang tinggi, jumlah siswa yang memiliki penguasaan kosakata sedang juga sama-sama berjumlah 44 siswa atau $46,30 \%$, sedangkan siswa yang memiliki penguasaan kosakata rendah berjumlah 7 siswa atau 7,40\%. Hasil tersebut memperlihatkan seberapa besar kemampuan penguasaan kosakata siswa kelas IX SMP Negeri di Kabupaten Magelang.

Penguasaan kosakata merupakan modal seseorang agar dapat berkomunikasi dengan orang lain baik secara lisan maupun tulis. Seseorang yang tidak memiliki penguasaan kosakata yang cukup dapat menyulitkan bahkan gagal untuk dapat saling berinterkasi dan menjalin 
suatu hubungan. Berdasarkan uji koefisien beta diperoleh nilai beta sebesar 0,582 dan bernilai positif. Hasil positif menunjukkan apabila penguasaan kosakata seseorang meningkat, maka keterampilan berpidato seseorang juga akan ikut meningkat. Selain itu, hasil uji hubungan tersebut menunjukkan koefisien determinasi penguasaan kosakata terhadap keterampilan berpidato sebesar $29,5 \%$, sedangkan $70,5 \%$ sisanya dijelaskan oleh faktor lain.

Interaksi merupakan salah satu cara manusia untuk menjalin hubungan dengan orang lain. Interaksi dalam bentuk pembicaraan dan penggunaan kosakata merupakan interaksi yang efisien dan langsung tepat sasaran. Barcroft, Sunderman, dan Schmitt (dalam Simpson, 2011: 576) mengutarakan bahwa kosakata amat diperlukan dalam berinterkasi supaya setiap individu dapat saling mengerti dan memahami. Kurangnya penguasaan kosakata dapat menyulitkan ketika dalam menyampaikan segala ide yang ada di dalam pikiran. Kosakata penting dalam pembicaraan maupun dalam berpidato. Seseorang yang memiliki kosakata yang terbatas akan menyebabkan interkasinya juga terbatas karena ide yang akan disampaikan sulit untuk diungkapkan dalam bahasa. Namun, seseorang yang memiliki penguasaan kosakata yang beragam akan lebih mudah berinterkasi untuk menyampaikan ide dan pendapat. Penguasaan kosakata yang beragam tentu sangat mendukung kegiatan berpidato karena pidato merupakan bentuk sarana interaksi lisan yang sebisa mungkin menarik dan memikat minat pendengar.

Penguasaan kosakata yang beragam tidak hanya membuat komunikasi menjadi semakin komunikatif, tetapi dapat juga mempengaruhi pola irama seseorang ketika berbicara. Stadler, Watson, Skahan. (2007) menyatakan bahwa kemampuan kosakata seseorang berhubungan dengan kemampuan berirama seseorang ketika berbicara. Kemampuan berirama juga dibutuhkan dalam berpidato karena penggunaan irama yang tepat akan lebih memudahkan pendengar untuk mengambil maksud yang orator sampaikan. Selain itu, penggunaan irama yang tepat akan lebih menarik banyak pendengar karena pendengar tidak kesulitan mengikuti rangkaian pidato. Penguasaan kosakata semestinya harus selalu ditingkatkan karena akan mempengaruhi kualitas interaksi dengan orang lain. Interaksi yang berkualitas akan menghindari kesalahpahaman ketika berbicara dengan orang lain. Selain itu, penguasaan kosakata yang tinggi juga memberikan manfaat dalam aktivitas berpidato.

Penguasaan kosakata yang tinggi tidak hanya membantu mempermudah dalam kegiatan interaksi dengan orang lain, tetapi juga bermanfaat dalam dunia pendidikan. Duff, Tomblin, dan Catts (2015) mengungkapkan bahwa kosakata dapat memengaruhi peluang akademis atau sosial seseorang. Seseorang yang memiliki penguasaan kosakata yang tinggi akan lebih mudah memahami bacaan dalam buku pelajaran ataupun ungkapan-ungkapan yang disampaikan oleh guru ketika mengajar.

Penguasaan kosakata yang cukup memang penting untuk dikuasai terutama oleh siswa karena penguasaan kosakata dapat meningkatkan prestasi. Belum tentu siswa yang selalu mendapatkan nilai buruk di sekolah disebabkan oleh kemampuan otak yang terbatas, bisa jadi hal tersebut dikarenakan penguasaan kosakata siswa yang terbatas. Penguasaan kosakata yang rendah dapat menyebabkan siswa kesusahan untuk memahami buku-buku pelajaran ketika bersekolah.

Penguasaan kosakata berhubungan dengan keterampilan berpidato yang sebelumnya telah diungkapkan oleh Aliani (2014). Penelitian ini memperkuat temuan sebelumnya tersebut. Penelitian Septiana Ria Aliani menyatakan bahwa kosakata berhubungan dengan keterampilan berpidato pada siswa SMA, tetapi temuan dalam penelitian ini dalam lingkup yang lebih rendah, yaitu siswa SMP.

\section{Hubungan Nilai Rapor terhadap Keterampi- lan Berpidato Siswa Kelas IX SMP Negeri di Kabupaten Magelang}

Nilai rapor merupakan salah satu bagian dari aktivitas kognitif. Aktivitas kognitif merupakan aktivitas mental yang dimiliki oleh setiap individu. Aktivitas mental tersebut dapat berupa aktivitas dalam hal mengingat, bertindak, ataupun aktivitas untuk memahami berbagai hal yang dihadapi. Setiap individu memiliki kemampuan yang berbeda-beda, sehingga 
berbeda-beda pula cara setiap individu dalam menghadapi berbagai permasalahan.

Berdasarkan hasil penelitian yang telah di analisis, diperoleh gambaran nilai rapor siswa yang duduk di kelas IX SMP Negeri di Kabupaten Magelang. Sampel penelitian yang berjumlah 95 siswa menyatakan bahwa 18 siswa atau $18,90 \%$ memiliki nilai rapor yang tinggi, 46 siswa atau $48,40 \%$ memiliki nilai rapor sedang, dan 31 siswa atau $32,60 \%$ memiliki nilai rapor yang rendah. Berdasarkan hasil tersebut dapat disimpulkan bahwa nilai rapor siswa kelas IX SMP Negeri di Kabupaten Magelang memiliki nilai rapor yang sedang.

Penelitian ini juga mengungkapkan bahwa nilai rapor memiliki hubungan terhadap keterampilan berpidato. Hubungan tersebut ditunjukkan oleh koefisien beta hasil penelitian sebesar 0,714 dan bernilai positif. Hasil positif menunjukkan bahwa apabila nilai rapor siswa meningkat, maka kemampuan dalam berpidato juga ikut meningkat. Selain itu, hasil uji hubungan tersebut juga menunjukkan koefisien determinasi nilai rapor terhadap keterampilan berpidato sebesar $20,7 \%$, sedangkan $79,3 \%$ sisanya dijelaskan oleh faktor lain.

Nilai rapor memiliki hubungan terhadap keterampilan berpidato. Aro, Poikkeus, Laakso, Tolvanen, dan Ahonen (2015) mengungkapkan bahwa berpidato memang dipengaruhi oleh kemampuan kognitif. Kemampuan kognitif seseorang membantu dalam memahami, mengembangkan, serta meningkatkan efektivitas dalam berpidato. Kemampuan memahami berguna untuk menggali topik, materi, suasana, ataupun untuk memahami pendengar, sehingga orator dapat menyampaikan informasi, ide, dan pendapat dengan tepat sasaran tidak menyimpang dari tujuan utama. Kemampuan mengembangkan bermanfaat bagi orator untuk mengambangkan topik ketika sudah berada di atas panggung. Suasana di luar dan di atas panggung sangatlah berbeda. Meskipun orator sudah mempersiapkan dengan detail materi pidato, tetapi ketika di atas panggung materi yang sudah dipersiapkan tersebut bisa lupa untuk disampaikan. Oleh sebab itu, kemampuan mengembangkan materi sangat diperlukan ketika berpidato, sehingga tidak terlihat gagap ketika gugup dan dapat mengatasi segala kendala ketika di atas panggung.
Zekveld, Rudner, Johnsrude, Heslenfeld, dan Ronnberg (2012) mengutarakan bahwa kemampuan setiap individu berbeda-beda. Perbedaan tersebut mempengaruhi kemampuan seseorang dalam meningkatkan kemampuan berbahasa. Meskipun berbeda-beda kemampuan dapatlah ditingkatkan dengan belajar. Kemampuan dalam berbahasa tidak kalah pentingnya dikuasai dengan baik oleh seorang orator. Tanpa memiliki kemampuan berbahasa yang baik dapat menyebabkan pendengar kesulitan mengikuti jalannya pidato. Kemampuan perlu untuk selalu ditingkatkan supaya dalam diri setiap individu memiliki kepekaan dan kritis terhadap berbagai hal.

Hubungan Minat Membaca, Penguasaan Kosakata, dan Nilai Rapor Terhadap Keterampilan Berpidato Siswa Kelas IX SMP Negeri di Kabupaten Magelang

Pidato merupakan kegiatan yang tidak mudah untuk dilakukan karena pidato memiliki banyak komponen yang harus dikuasai. Berdasarkan hasil penelitian yang telah di analisis dapat dideskripsikan bahwa kemampuan berpidato siswa kelas IX SMP Negeri di Kabupaten Magelang memiliki kemampuan yang bervariasi. Sampel penelitian yang berjumlah 95 siswa diperoleh gambaran bahwa 17 siswa atau $17,90 \%$ siswa memiliki keterampilan berpidato yang tinggi, 50 siswa atau $52,60 \%$ siswa memiliki keterampilan berpidato sedang, dan 28 siswa atau $29,50 \%$ siswa memiliki nilai rapor yang rendah. Berdasarkan data tersebut dapat disimpulkan bahwa keterampilan berpidato siswa kelas IX SMP Negeri di Kabupaten Magelang dalam kategori sedang.

Berdasarkan hasil uji F terbukti bahwa minat membaca, penguasaan kosakata, dan nilai rapor memiliki hubungan terhadap keterampilan berpidato siswa kelas IX SMP Negeri di Kabupaten Magelang. Hasil uji hubungan tersebut diketahui dari nilai p sebesar 0,000. Hal tersebut menunjukkan bahwa terdapat hubungan antara variabel bebas dan terikat secara berganda karena nilai $p$ kurang dari dari taraf kesalahan $5 \%$. Selain itu, diperoleh nilai determinasi sebesar $48,5 \%$ dan sisanya $51,5 \%$ dijelaskan oleh faktor lain. Hasil penelitian ini sejalan dengan penelitian yang telah dilakukan oleh 
Yuliatun (2009) maupun Endarwati (2013) yang sama-sama menyatakan bahwa minat membaca dan penguasaan kosakata secara bersama-sama berhubungan dengan keterampilan berpidato.

Hasil penelitian menunjukkan apabila minat membaca, penguasaan kosakata, dan nilai rapor tinggi, maka keterampilan siswa dalam berpidato juga akan ikut tinggi. Namun, apabila minat membaca, penguasaan kosakata, dan nilai rapor rendah, maka keterampilan berpidato siswa juga akan ikut rendah. Minat membaca, penguasaan kosakata, dan nilai rapor menjadi salah satu faktor penting yang dapat meningkatkan kemampuan berpidato. Oleh sebab itu, faktor-faktor tersebut tidak boleh disepelekan supaya kemampuan dalam berpidato dapat meningkat.

\section{SIMPULAN}

Berdasarkan analisis data dan pembahasan yang telah diuraikan pada, maka dapat ditarik kesimpulan sebagai berikut. Pertama, minat membaca memiliki hubungan yang positif dan signifikan terhadap keterampilan berpidato siswa kelas IX SMP Negeri di Kabupaten Magelang. Minat membaca memberikan kontribusi sebesar $29,9 \%$ terhadap keterampilan berpidato, sedangkan $70,1 \%$ sisanya berasal dari faktor lain. Kedua, penguasaan kosakata memiliki hubungan yang positif dan signifikan terhadap keterampilan berpidato siswa kelas IX SMP Negeri di Kabupaten Magelang. Penguasaan kosakata memberikan kontribusi sebesar 29,5\% terhadap keterampilan berpidato, sedangkan sisanya $70,5 \%$ berasal dari faktor lain. Ketiga, nilai rapor memiliki hubungan yang positif dan signifikan terhadap keterampilan berpidato siswa kelas IX SMP Negeri di Kabupaten Magelang. Nilai rapor memberikan kontribusi sebesar 20,7\% terhadap keterampilan berpidato, sedangkan sisanya $79,3 \%$ berasal dari faktor lain. Keempat, minat membaca, penguasaan kosakata, dan nilai rapor memiliki hubungan yang positif dan signifikan secara berganda terhadap keterampilan berpidato. Secara berganda minat membaca, penguasaan kosakata, dan nilai rapor memberikan kontribusi sebesar $48,5 \%$ terhadap keterampilan berpidato, sedangkan sisanya $51,5 \%$ berasal dari faktor lain.

\section{DAFTAR PUSTAKA}

Aro, T., Anna, M. P., Marja, L. L., Asko, T., Timo, A. 2015. Associations Between Private Speech, Behavioral Self-Regulation, and Cognitive Abilities. Eric. Volume 39, VI, hlm. 508-518.

Dalman. 2013. Keterampilan Membaca. Jakarta: PT Rajawali Pres.

Duff, D., J. Bruce, T., \& Hugh, C. 2015. The Influence of Reading on Vocabulary Growth: a Case for Matthew Effect. ProQuest. Volume 58, hlm. 853-864.

Endarwati. 2013. Hubungan antara Minat Membaca dan Penguasaan Kosakata Dengan Keterampilan Berbicara Siswa Kelas VI SD Negeri se Gugus Diponegoro Batuwarno Wonogiri. Poltalgaruda. Volume 22, no 3, hlm. 241-254.

Hendrikus, D. W. 1991. Retorika Terampil Berpidato, Berdiskusi, Berargumentasi, Bernegosiasi. Yogyakarta: Kanisius.

Keraf, G. 2004. Komposisi. Ende: Nusa Indah.

Reed, S. K. 2011. Kognisi Teori dan Aplikasi Edisi 7 (Terjemahan). Jakarta: Salemba Hmanika.

Aliani, S. R. 2014. Pengaruh Penguasaan Kosakata dan Penguasaan Gramatika Terhadap Keterampilan Berbicara Bahasa Jerman Peserta Didik Kelas XI SMA Negeri 1 Minggir Sleman. Skripsi. Tidak diterbitkan. Program Studi Pendidikan Bahasa Jerman, Universitas Negeri Yogyakarta.

Simpson, J. 2011. The routledge hanbook of applied linguistics. London: Routledge Taylor \& Francis grup.

Smith, E. E., \& Stephen, M. K. 2014. Psikologi kognitif pikiran dan otak.(Terjemahan). Yogyakarta: Pustaka Pelajar.

Stadler, M.A., Magie, W., \& Sarah, S. 2007. 2007. Rhyming and vocabulary effects of lexical restructuring. ProQuest. Volume 28, IV, hlm. 197-205.

Tarigan, H. G. 2008. Membaca sebagai suatu keterampilan berbahasa edisi revisi. Bandung: Angkasa.

Yuliatun, S. 2009. Hubungan Minat Membaca dan Penguasaan Kosakata dengan Keterampilan Berbicara Siswa Kelas 
VI Sekolah Dasar Negeri 2 Bulusulur di Kecamatan Wonogiri Kabupaten Wonogiri. Tesis. Tidak diterbitkan. Program Studi Pendidikan Bahasa Indonesia Program Pascasarjana, Universitas Sebelas Maret Surakarta.
Zekveld, A.A., Rudner, M., Johnsrude, I. S., Heslenfeld, D. J., Ronnberg, J. 2012. Behavioral and Fmri Evidence That Cognitive Ability Modulates the Effect Of Semantic Context on Speech Intelligibility. Eric. Volume 122, II, hlm 103-113. 